\title{
JOÃO-ALGUÉM, JOÃO-NINGUÉM: O DUPLO EM JOÃO GILBERTO NOLL
}

Gustavo Cerqueira Guimarães*

RESUMO: Este ensaio pretende expor algumas das principais contribuições teóricas de Roland Barthes e Michel Foucault acerca do autor nos Estudos Literários. $\mathrm{E}$, em seguida, pretende-se articulá-las à obra de João Gilberto Noll, demonstrando algumas de suas estratégias para provocar uma tensão entre autor/ narrador, a exemplo do emprego do nome João em quatro de seus romances - $A$ fúria do corpo (1981) Bandoleiros (1985), Canoas e marolas (1999) e Berkeley em Bellagio (2002).

PALAVRAS-CHAVE: Literatura Brasileira; Teoria da literatura; Autor; Duplo.
* gustavocguimaraes@hotmail.com Doutor e Mestre em Estudos Literários pela Faculdade de Letras da UFMG.

RÉSUMÉ: Cet essai vise à exposer certaines des principales contributions théoriques de Roland Barthes et Michel Foucault sur l'auteur dans les Études Littéraires. Puis nous avons l'intention de les articuler au travail de João Gilberto Noll, ce qui démontre certaines de leurs stratégies pour occasionner une tension entre l'auteur / narrateur, comme l'utilisation du nom de João dans quatre de ses romans $A$ fúria do corpo (1981), Bandoleiros (1985), Canoas e marolas (1999) e Berkeley em Bellagi (2002)

MOTS-CLÉS: Littérature Brésilienne; Auteur; Double; Théorie de la Littérature. 


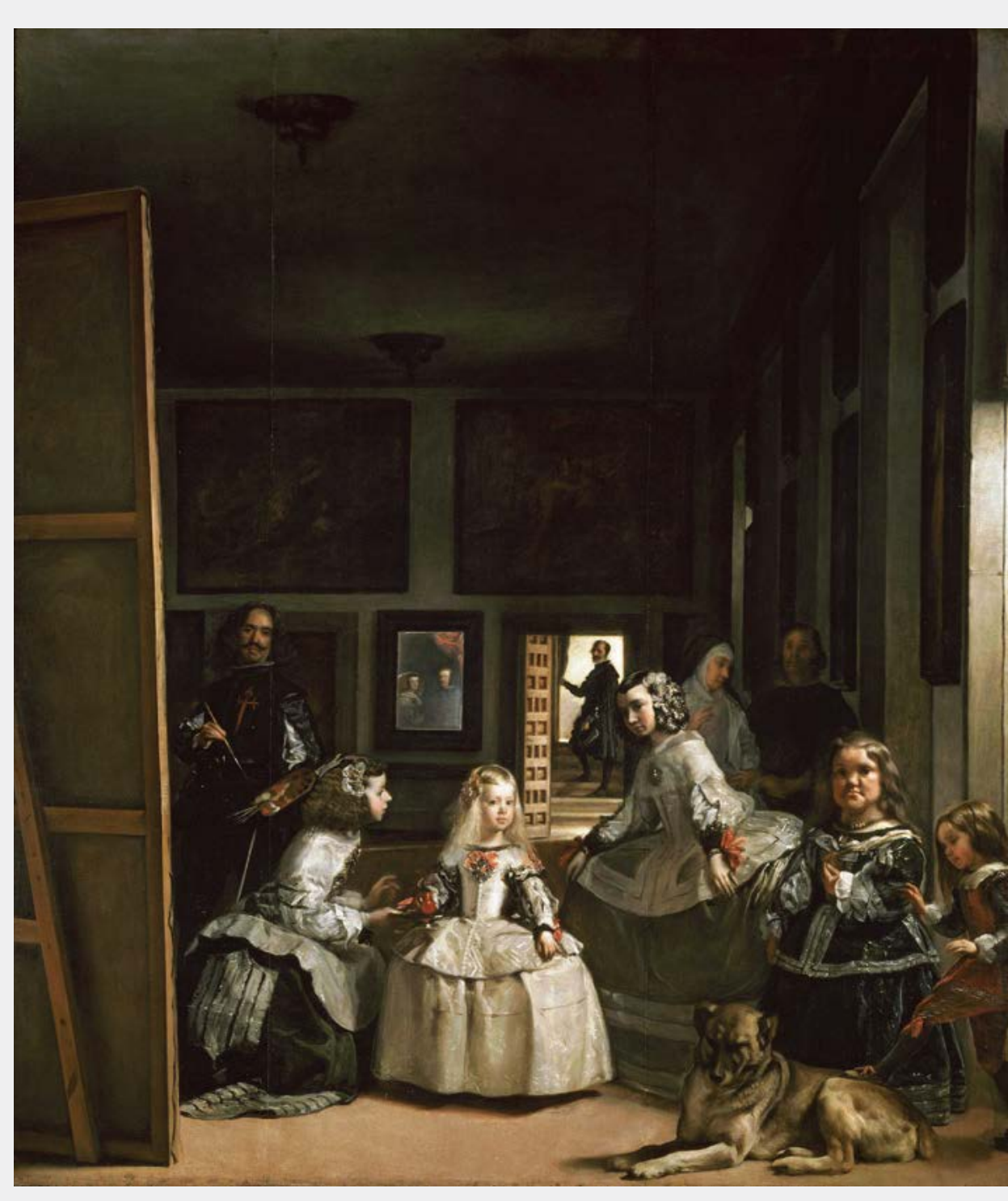

FIGURA 1

Para a metafísica clássica, não havia nenhum inconveniente em "dividir" a pessoa (Racine: "Trago dois homens em mim"); muito pelo contrário, provida de dois termos opostos, a pessoa funcionava como um bom paradigma (alto/baixo, carne/espírito, céu/terra); as partes em luta se reconciliavam na (alto/baixo, carne/ espirito, céu/terra); as partes em luta se reconciliavam na hoja de um sentido: o sentido do Homem. Eis por que, quando falamos hoje de um contradições simples, suas duplas postulaçōes, etc.; é uma difração que se visa, uma fragmentação em cujo jogo não resta mais nem núcleo principal, nem estrutura de sentido: não sou contraditório, sou disperso.

Roland Barthes, $R B$ por $R B$

A temática do duplo se inscreve no campo da literatura incessantemente por meio de inúmeras imagens especulares desde os tempos antigos, como o mito de Narciso, por exemplo. No entanto, somente a partir da modernidade tem a conotação que se confere hoje, como bem nos adverte o pensador francês Michel Foucault ao propor uma instigante leitura da imagem pictórica Las meninas (Fig. 1), do espanhol Diego Velásquez, proferida em uma entrevista:

Bem, no século XVII, no fundo, não era nunca o homem, o rei, que estava presente no interior mesmo do saber e do conhecimento. Ele era referenciado do exterior por todo um sistema de referências e análises. Nós, [hoje], estudamos as representações de imaginações, o coração, as paixões, etc... Mas o homem mesmo, o homem em carne e osso, o homem com seu corpo, com seu sexo, com suas determinações históricas 
1. Cf.: FOUCAULT apud CALDERÓN. Foucault por ele mesmo (Documentário). “Neste quadro [Las meninas], vemos quadro [Las meninas], vem pintando uma tela. Não sabemos o que representa essa tela, nem mesmo se ela foi começada, pois nós a vemos ao inverso. Ora, no meio do quadro que se expande para a parede, no fundo da peç há um pequeno homem. E num há um pequeno homem. E num espelho vemos o reflexo do consequência podemos concluir, mas não é simplesmente umá conclusáo, que o pintor está representan qu sobre a tela o rei jovem prina espá jovei princesa está olhando o pintados. Reflexo que mostra intados. Reflexo que mostra ingenuamente, e na sombra, aquilo que todos olham no que num encanto, o que fata que num encanto, o que falta a cada olhar: ao do pintor, o modelo que é recopiado no quadro pelo seu duplo representado; ao do rei, seu retrato que se completa nesse lado da tela que ele náo pode distinguir do lado em que está; ao do espectador, o centro real da cena, cujo lugar ele assumiu como que por intrusão. Mas, talvez, essa generosidade do espelho seja simulada, talvez esconda tanto ou mais do que manifesta"

2. NOLL. Berkeley em Bellagio, p. 29. precisas não existia. Ele só estava no estado de representação, ele mesmo não estava lá nunca. ${ }^{1}$

Conjugam-se essas ponderações de Michel Foucault acerca da representação na contemporaneidade, somadas a algumas outras proposições suas e de seu contemporâneo Roland Barthes, que veremos a seguir, para pensarmos a maneira como elas operam na literatura do romancista gaúcho João Gilberto Noll, sobretudo no que diz respeito à autoria nas artes literárias. Essas correlações incidem por meio do "próprio" escritor duplicado no espaço literário cuja incidência é significativa em sua obra, tomando contornos singulares por meio da "presença fantasmagórica" do autor em "carne e osso", também nomeado João, com suas implicações éticas, suas pulsões, seu desejo. Vejam-se, por exemplo, as reflexões do narrador de Berkeley em Bellagio (2002):

quem será esse homem aqui que já não se reconhece ao se surpreender de um golpe num imenso espelho ornado em volta de dourados arabescos, um senhor chegando à meia-idade [...] sem ter onde cair morto em sua própria terra. [...] Vivia ali sobretudo acorrentado a ele mesmo, a esse brasileiro se interrogando que imagem poderia causar na "Catedral" americana com seu jeito aloirado, sobrenome alemão, vagando sem saber por que vagava tanto por aqueles salões dos cortesãos. ${ }^{2}$
A partir desse e de outros trechos nollianos, o leitor é convidado, ou mesmo impelido, a se perguntar quem é esse escritor ou quem é esse personagem, por vezes anônimo que se enuncia sob a aparente autobiografia, parecendo em muitos momentos enunciar a "verdade" de uma vida, tal qual expresso em Lorde (2004). Para dar conta dessa problemática, propõe-se primeiramente pensar a partir das postulações teóricas daqueles que dissertaram sobre o assunto em alguns textos que se tornaram cânones no campo dos estudos literários. Seguem-se alguns deles, a título de revisão dessa temática, como o texto "O que é um Autor", de Michel Foucault, para em seguida se verificar mais detidamente como se dá a imbricação desses indícios em João Gilberto Noll.

\section{"ALGUÉM DISSE, O QUE IMPORTA QUEM FALA"}

Em 1968, quando se torna público o texto "A morte do autor", Roland Barthes contesta certa parte geral da teoria e da crítica literária que só faziam reforçar o "império do Autor". As análises e comparações realizadas entre a biografia e a obra do autor eram, a seu ver, muito diretas e grosseiras:

O autor ainda reina nos manuais de história literária, nas biografias de escritores, nas entrevistas dos periódicos e na própria consciência dos literatos, ciosos por juntar, graças ao seu diário íntimo, a pessoa e a obra; a imagem da literatura que se pode encontrar na cultura corrente está tiranicamente cen-
EM TESE
BELO HORIZONTE
v. 19
N. 1
JAN.-ABR. 2013
GUIMARÃES. João-Alguém, João-Ninguém: 0 duplo em João Gilberto Noll
P. $59-75$ 
3. BARTHES. A morte do autor. $O$ rumor da língua, p. 58.

4. BARTHES. A morte do autor. $O$ rumor da língua, p. 64. tralizada no autor, sua pessoa, sua história, seus gostos, suas paixões; a crítica consiste ainda, o mais das vezes, em dizer que a obra de Baudelaire é o fracasso do homem Baudelaire. ${ }^{3}$

O texto barthesiano demarca, sobremaneira, a morte do autor para o advento do leitor. Assim, a escrita não se fecharia em um único sentido; ou seja, no significado 'original' dado pelo autor, tendo-se em vista que o próprio leitor se torna integrante do jogo literário, tornando-se ele um espaço

onde se inscrevem, sem que nenhuma se perca, todas as citações de que é feita uma escritura; a unidade do texto não está em sua origem, mas no seu destino, mas esse destino já não pode ser pessoal: o leitor é um homem sem história, sem biografia, sem psicologia; ele é apenas esse alguém que mantém reunidos em um mesmo campo todos os traços de que é constituído o escrito. ${ }^{4}$

Esse talvez seja um dos motes capitais a se destacar em Barthes, pois com a atribuição do leitor como peça fundamental para a efetivação do ato de leitura, o autor perde o lugar central, o de detentor de sua obra, caminhando para o seu "desaparecimento". A obra, então, realiza-se nessa interação, momento em que o leitor integra o seu imaginário ao texto.
Contudo, talvez seja categórico em demasia afirmar simplesmente que o autor "desapareceu". A afirmativa de Barthes, em um tom bastante combativo, vale dizer, muito se deve ao contexto francês da época, quando muito se privilegiava o autor em detrimento do leitor. Nesse sentido, próximo a essas ideias, já em 1969, na conferência "O que é um Autor?”, Michel Foucault amplia a discussão. Em tom mais investigativo do que exclamativo, pronuncia que, na leitura literária, trata-se de notar que modo e segundo quais regras se forma, circula e funciona a noção de autor dentro de uma sociedade. Para Foucault, não é suficiente repetir como "afirmação vazia" que o autor morreu, e

que se tenham absorvido rigorosamente todas as consequências inerentes a essa constatação, nem que se tenha avaliado com exatidão a medida do acontecimento. Mais precisamente, parece-me que um certo número de noções que hoje são destinadas a substituir o privilégio do autor o bloqueiam, de fato, e escamoteiam o que deveria ser destacado. ${ }^{5}$

Foucault propõe a análise de duas instâncias para se pensar sobre o "apagamento" do autor: a obra e a escrita. Sobre a primeira, seu texto interroga da seguinte maneira: "O que é uma obra? O que é, pois, essa curiosa unidade que se designa com o nome de obra? De quais elementos ela se compõe? Uma obra não é aquilo que é escrito por aquele que é um
5. FOUCAULT. O que é um Autor? Ditos e escritos III, p. 269 
6. FOUCAULT. O que é um Autor? Ditos e escritos III, p. 269.

7. FOUCAULT. O que é um Autor? Ditos e escritos III, p. 270-1.

8. FOUCAULT. O que é um Autor? Ditos e escritos III, p. 270-1.

9. Cf.: O escritor por ele mesmo: leituras de João Gillberto Noll, 2002.

10. João Gilberto Noll publicou pequenos contos, duas vezes por semana, intitulados Relámpagos, no jornal Folha 1998 áé deze de asto de 1998 ate dezembro de 2001. Em 2004 colaborou quinzenalmente com o caderno Pensar" do Jornal Correio Braziliense, de Brasilia, com extensos contos que ocupavam duas páginas do suplemento. No início da carreir jornal Correio da Manhã.

autor?". ${ }^{6}$ Por outro lado, a respeito da escrita, Foucault diz que, "com sutileza, ela ainda preserva a existência do autor". A constatação desta presença "arrisca manter os privilégios do autor sob a salvaguarda do a priori: ele faz subsistir, na luz obscura da neutralização, o jogo das representações que formaram uma certa imagem do autor". ${ }^{8}$

Esses questionamentos e essas proposições são bem pertinentes para se refletir nos dias atuais sobre o fato de o nome a imagem do autor estarem tão vinculados às suas obras, tanto pelas suas próprias intenções de se projetarem nos textos por meio de marcas biográficas quanto pelas exigências do mercado editorial. Para tanto, ocorrem, dentre outros, muitos eventos nos quais o autor é demandado a se envolver; enumerem-se algumas destas situações: a) estampam-se suas fotografias na capa ou no interior dos livros em alusão, por vezes, a uma relação entre o autor e o personagem, e, quase obrigatoriamente, uma pequena biografia acompanha a edição dos livros - presente em Noll, por exemplo; b) há um crescente lançamento de obras lítero-musicais em CDs, pelos quais se narram trechos de sua obra com a sua própria voz e dicção, que se tornam coladas à enunciação - o autor por ele mesmo; ${ }^{9}$ c) promovem-se inúmeras entrevistas, veiculadas em diversas mídias - internet, Tv, rádio, jornal -, além da prática constante de publicação de textos e/ou opiniões em blogs, redes sociais ou em jornais; ${ }^{10} \mathrm{~d}$ ) participação dos

escritores em prêmios de literatura, palestras universitárias, eventos literários, nos quais se demanda o pronunciamento dos pormenores de sua vida privada e/ou sobre os modos e as condições de escrita - onde, quando, como e por que se escreve; ${ }^{11}$ e) ocorrem frequentemente ofertas de bolsa para escritores residentes em outros países, objetivando-se a criação de obra literária, de modo que, por vezes, o autor ficcionaliza sua própria experiência; ${ }^{12}$ f) observa-se uma crescente demanda, por uma gama considerável de leitores, de biografias sobre escritores, além do interesse por documentários, diários íntimos, entrevistas, cartas, exposições de "rascunho" das obras ou dos objetos pessoais. Ou seja, há uma grande fetichização dos arquivos (espólios) dos escritores.

Os próprios personagens de João Gilberto Noll trazem algumas questões acerca desse interesse do leitor por seus autores preferidos, como por exemplo em Bandoleiros (1985), Lorde ou Berkeley em Bellagio, no qual é demonstrado o interesse do personagem-narrador pela troca de correspondências entre dois pensadores: "Nas pausas lia a correspondência entre Hannah Arendt e Heidegger e, de fato, gostava então mais desse núcleo íntimo do conhecimento, onde observava o malogro existencial de alguns lutadores de ideias, dessas ideias que tentavam formar com obsessão a tal ciência humana de seu tempo". ${ }^{13} \mathrm{Ou}$ ainda em O quieto animal da esquina (1991), no qual o narrador, um ainda jovem aspirante
11. João Gilberto Noll foi laureado em cinco ocasiões pelo Prêmio Jabuti, além, dentre outros, do Prêmio de Literatura da Associação Paulista de Críticos de Arte (APCA) em 2006 categoria contos (A máquina de ser); Prêmio da Fundação Guggenheim, em 2002; Prêmio Ficção da Academia Brasileira de Letras, em 2004 (Mínimos Múltiplos Comuns). O autor foi finalista do Prêmio Portugal Telecom em 2003 com Berkeley em Bellagio e, em 2009, $2^{\circ}$ lugar, com Acenos e afagos.

12. Em 1982, João Gilberto Noll recebeu a bolsa do Programa de Escritores da Universidade de Yowa, EUA. Em 1996, passou um mês em Berkeley, EUA, como escritor visitante da Universidade da Califórnia, e, em 1997 foi convidado para lecionar Literatura e Cultura Brasileira nesta universidade. Em 2004, Noll morou dois meses em Londres como escritor-residente no King's College. Em 1988, recebeu a bolsa da Fundação Vitae para escrever Hotel Atlântico. No âmbito ficcional, os narradores-escritores de Berkeley em Bellagio e Lorde também receberam bolsas para residirem no exterior, na Itália e na Inglaterra, respectivamente.

13. NOLL. Berkeley em Bellagio, p. 20.

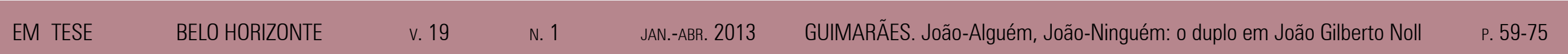


14. NOLL. O quieto animal da esquina, p. 8.

15. FOUCAULT. Ditos e escritos III, p. 270. arte literária, demonstra, além de seu interesse por poesia, seu fascínio pela intimidade dos escritores:

eu muitas vezes como agora ia me sentar na Biblioteca Pública a alguns passos daquele sebo, pegava vidas de poetas, um mais estranho que o outro, tinha um que nunca correra atrás de uma trepada, nunca tinha fodido com ninguém, morreu as sim, casto, outro cultivava escondido aparas de suas próprias unhas, botava as aparas num pequeno frasco e como que as reverenciava, tangido por algum sentimento que ele não sabia decifrar. ${ }^{14}$

Mesmo que essa demonstração seja por uma via irônica não deixa de nos interessar a maneira pela qual João Gilberto Noll tece esporadicamente um pensamento sobre o que é exercer a atividade de escritor nos dias de hoje. Assim, todo esse jogo, no qual o autor está inserido, com raríssimas exceções (se é que é possível estar fora de alguma maneira) faz parte do que chamamos hoje de literatura, contribuindo para que se construa uma imagem do autor na sociedade ainda que difusa, "de tal maneira que é insuficiente afirmar: deixemos o escritor, deixemos o autor e vamos estudar, em si mesma, a obra. A palavra 'obra' e a unidade que ela designa são provavelmente tão problemática quanto a individualidade do autor", ${ }^{15}$ orienta-nos Michel Foucault.
Há, portanto, uma singularidade quanto ao status da obra quando assim a nomeamos. $\mathrm{O}$ autor se diferencia de um discurso cotidiano quando obedece às regras de produção e circulação de suas obras. A rarefação do discurso - quem diz como diz, quando diz - torna-se um vetor extremamente expressivo nos dias atuais. Foucault chega até a afirmar que “o anonimato literário não é suportável para nós; só aceitamos na qualidade de enigma. A função autor hoje em dia atua fortemente nas obras literárias" ${ }^{16}$

Foucault, em sua aula inaugural no Collège de France em 2 de dezembro de 1970, publicada sob o título A ordem do discurso, diz que

Seria absurdo negar, é claro, a existência do indivíduo que escreve e inventa. Mas penso que - ao menos desde uma certa época - o indivíduo que se põe a escrever um texto no horizonte do qual paira uma obra possível retoma por sua conta a função do autor: aquilo que ele escreve e o que não escreve, aquilo que desenha, mesmo a título de rascunho provisório, como esboço da obra, e o que deixa, vai cair como conversas cotidianas. Todo este jogo de diferenças é prescrito pela função do autor, tal como a recebe de sua época ou tal como ele por sua vez, a modifica. Pois embora possa modificar a imagem tradicional que se faz de um autor, será a partir de uma nova posição do autor que recortará, em tudo o que poderia
16. FOUCAULT. O que é um Autor? Ditos e escritos III, p. 276 
17. FOUCAULT. $A$ ordem do discurso, p. 28-9.

18. FOUCAULT. O que é um Autor? Ditos e escritos III, p. 279-80. ter dito, em tudo o que diz todos os dias, a todo momento, o perfil ainda trêmulo de sua obra. ${ }^{17}$

Essa conjectura ratifica a presença do autor, visto que o seu nome não se refere meramente à sua civilidade, mas sim à sua "função". Dessa forma, a autoria aparece como mais um processo de subjetivação do sujeito que escreve, pois independentemente de sua vontade, estará sempre inserido em um determinado tipo de regras que veiculam a sua obra $\mathrm{e}$ por conseguinte, a sua imagem. Foucault melhor descreve a função autor da seguinte forma:

[a] A função autor está ligada ao sistema jurídico e institucional que contém, determina, articula o universo dos discursos;

[b] ela não se exerce uniformemente e da mesma maneira sobre todos os discursos, em todas as épocas e em todas as forma de civilização; [c] ela não é definida pela atribuição espontânea de um discurso ao seu produtor, mas por uma série de operações específicas e complexas; [d] ela não remete pura e simplesmente a um indivíduo real, ela pode dar lugar simultaneamente a vários egos, a várias posições-sujeitos que classes diferentes de indivíduos podem vir a ocupar. ${ }^{18}$

Ou seja, por meio dessas atribuições à sua função, o autor está sob a jurisprudência dos modos de produção do discurso de acordo com os dispositivos que lhes são contemporâneos. Há pactos formulados, mesmo que tácitos, entre os autores, os leitores e todo o arsenal que ampara os costumes de fabricação literária.

Da mesma maneira, no texto "O pacto autobiográfico" (1975), escrita seminal das teorias autobiográficas na literatura, que também agregam algumas das discussões trazidas até aqui, Philippe Lejeune afirma que o que o escritor faz é nos conduzir aos pactos de leitura firmados entre ele - autor - e o leitor, determinando implícita ou explicitamente o modo de leitura do texto. Não se tem a intenção, aqui, de problematizar as questões acerca da escrita ou do gênero autobiográficos, caso específico desse texto de Lejeune, no entanto as suas teorias igualmente nos são úteis para corroborar a ideia de Foucault de que os romances são lidos também sob um contrato de leitura. Assim, é no "nível global que se define a autobiografia", pois ela "é tanto um modo de leitura quanto um tipo de escrita, é um efeito contratual historicamente variável". ${ }^{19}$

Em "O pacto autobiográfico", Lejeune dissemina um dos mais promissores conceitos de sua teoria, segundo a qual "o leitor é assim convidado a ler os romances não apenas como ficcões remetendo a uma verdade da 'natureza humana', mas também como fantasmas reveladores de um indivíduo". ${ }^{20}$ Lejeune denomina essa forma indireta de discurso de pacto fantasmático, e diz ainda que esse pacto vem se proliferando cada vez mais, agregando aos estudos literários um campo
19. LEJEUNE. O pacto autobiográfico, p. 46

20. LEJEUNE. $O$ pacto autobiográfico, p. 43 
21. BARTHES. Orumor da língua, p. 354-5.

22. Cf.: BARTHES. Roland Barthes por Roland Barthes, p. 7. rico para investigação: o caráter lúdico, o jogo entre autor e leitor, na linhagem sem dúvida alguma de Maurice Blanchot e Roland Barthes. Este último, por exemplo, a respeito de Marcel Proust, afirma que podem existir muitos elementos da vida pessoal do autor em suas obras. Porém, a voz é hipotética pois essa voz narrativa - e aqui se inclui a voz nolliana -

põe em cena - ou em escritura - um 'eu' (o Narrador); mas esse 'eu', se assim se pode dizer, já não é exatamente um 'eu' (sujeito e objeto da autobiografia tradicional): 'eu' não é aquele que se lembra, se confia, se confessa; é aquele que enuncia; quem é posto em cena por esse 'eu' é um 'eu' de escritura, cujas ligações com o 'eu' civil são incertas, deslocadas. ${ }^{21}$

O semiologista abordou bastante essa temática ao longo de toda sua trajetória de produção crítica. Em Roland Barthes por Roland Barthes, o autor, além de expor cenas autobiográficas por meio da encenação ensaística (em palavras), apresenta também fotografias pessoais de seu arquivo em cerca de cinquenta páginas. Esses retratos, no entanto, adverte o autor logo no início, não se referem mais a ele, e ao mesmo tempo não se referem "a mais ninguém". ${ }^{22} \mathrm{Ou}$ seja, é ele ao mesmo tempo que não se é, porque "abarcando todo o campo parental, a imageria age com um médium e me põe em relação com o 'isto' de meu corpo; ela suscita em mim uma

EM TESE

BELO HORIZONTE

v. 19

N. 1

JAN.-ABR. 2013 espécie de sonho obtuso, cujas unidades são dentes, cabelos, um nariz uma magreza, pernas com meias compridas". ${ }^{23}$

Em $R B$ por $R B$, livro fundamental para se pensar sobre essa relação da imagem fotográfica com a memória e a (auto) biografia, o autor tece ainda algumas reflexões teóricas importantes para se pensar o autor contemporâneo: "tudo isto deve ser considerado como dito por uma personagem de romance - ou melhor, por várias". ${ }^{24} \mathrm{E}$, em "Da obra ao texto" (1971), é ainda mais aclarada essa ideia, garantindo que o autor somente deve voltar à obra

a título de convidado; se for romancista, inscreve-se nele como uma das personagens; [...] a sua inscrição já não é privilegiada, paterna, alética, mas lúdica; [...] a sua vida já não é a origem das suas fábulas, mas uma fábula concorrente com a obra; [...] a palavra 'bio-grafia' readquire um sentido forte, etimológico; e, ao mesmo tempo, a sinceridade da enunciação, verdadeira 'cruz' da moral literária, torna-se um falso problema: também o $e u$ que escreve o texto nunca é mais do que um $e u$ de papel. ${ }^{25}$

Susan Sontag, no ensaio "Relembrando Barthes" (1980), afirma que o semiólogo "tinha uma relação amorosa com a realidade - e com a escritura, que para ele era a mesma coisa”. ${ }^{26}$ Ao se perspectivar por este prisma, os limites entre vida e obra são de fato inseparáveis. Desse modo, forçar a delimitação poderia nos impor um falso problema, tamanho
23. BARTHES. Roland Barthes por Roland Barthes, p. 7.

24. BARTHES. Roland Barthes por Roland Barthes, p. 129.

25. BARTHES. O rumor da língua, p. 72.

26. SONTAG. Sob o signo de Saturno, p. 129. 
27. BARTHES. Roland Barthes por Roland Barthes, p. 85.

28. FOUCAULT. Ditos e escritos III, p. 269. é o imbricamento de tais instâncias em Roland Barthes, em João Gilberto Noll e em diversos outros ensaístas e escritores contemporâneos.

Até o momento, então, tem-se algumas pistas para delinear as direções segundo as quais o objeto proposto em análise será tratado. Por um lado, esse eu que se apresenta nos romances não é exatamente o eu do autor, mas sim "pedaços" desse $e$, fragmentado e dissimulado, devido aos limites da representação do referente. Por outro lado, há um eu, uma "sombra", que se apresenta ao leitor por intermédio da imagem que se forma do autor, mesmo que provisória, pois "aquilo que o fantasma impõe é o escritor tal como podemos vê-lo em seu diário íntimo, é o escritor menos sua obra: form suprema do sagrado: a marca e o vazio". ${ }^{27}$ Colocada dessa forma, por meio de uma aparente contradição, "a morte do autor" proclamada por Barthes efusivamente no ensaio homônimo, apresenta-se já em seus textos subsequentes bem mais coerente e aceitável.

Essa "presença-ausência" do literato em um só tempo junto à obra é registrada também em Michel Foucault - "a marca do escritor não é mais do que a singularidade de sua ausência: é preciso que ele faça o papel do morto no jogo da escrita",$-^{28}$ e corroborada por Giorgio Agamben, pensador italiano atuante nos dias de hoje, ao principiar no ensaio "O autor como gesto" (2005) uma análise do pronunciamento de Samuel Beckett, "O que importa quem fala, alguém disse, o que importa quem fala", ${ }^{29}$ apontado em "O que é um Autor?”, de Foucault. Há, nessa frase de Beckett, "alguém que, mesmo continuando anônimo e sem rosto, proferiu o enunciado, alguém sem o qual a tese, que nega a importância de quem fala, não teria podido ser formulada. $\mathrm{O}$ mesmo gesto que nega qualquer relevância à identidade do autor afirma, no entanto, a sua irredutível necessidade". ${ }^{30}$

Nesse sentido, portanto, a marca do escritor reside na singularidade de sua ausência; o mesmo gesto nega e afirma sua presença, como bem se posiciona Agamben a partir de algumas das reflexões foucaultianas abordadas aqui.

O autor marca o ponto em que uma vida foi jogada na obra. Jogada, não expressa; jogada, não realizada. Por isso, o autor nada pode fazer além de continuar, na obra, não realizado e não dito. Ele é o ilegível que torna possível a leitura, o vazio lendário de que procedem a escritura e o discurso. O gesto do autor é atestado na obra a que também dá vida, como uma presença incongruente e estranha [...]. O gesto do autor garante a vida da obra unicamente através da presença irredutível de uma borda inexpressiva. [...] E assim como em certos livros velhos que reproduzem ao lado do frontispício o retrato ou a fotografia do autor, nós procuramos em vão, nos seus traços enigmáticos, os motivos e o sentimento da obra como o exer-
29. BECKETT apud AGAMBEN. Profanações, p. 55

30. AGAMBEN. Profanações, p. 55
EM TESE
BELO HORIZONTE
v. 19
N. 1
JAN.-ABR. 2013
GUIMARÃES. João-Alguém, João-Ninguém: o duplo em João Gilberto Noll
P. $59-75$ 
31. AGAMBEN. Profanações, p. 62-3. go intratável, que pretende ironicamente deter o seu inconfessável segredo. ${ }^{31}$

\section{JOÃO-ALGUÉM, JOÃO-NINGUÉM}

Escrevo porque não sei por que escrevo. Porque o mundo parece regido por um distúrbio secreto que, desconfio, não se dissolverá enquanto eu puder manter a fronte latejante. Escrevo quem sabe este texto agora por ser a forma mais eficaz de vislumbrar minhas possiveis razões para a escrita.

O fascínio da atividade literária vem para mim um pouco disso: da soma vertiginosa de golfadas, onde você pega quase sem querer alguns contornos do mistério detonador dos dramas e da comédia humana.

J. G. Noll, O escritor por ele mesm

A relação entre vida e obra e as questões em torno da autoria desenvolvidas até este ponto, com o auxílio de Barthes, Lejeune, Foucault e Agamben, têm a presteza de nos auxiliar neste momento ao se tomar com exclusividade a obra de João Gilberto Noll para a análise. Tais elementos se tornam igualmente um componente agonístico em grande parte de sua literatura, na qual passa a existir a "sombra" indelével e ao mesmo tempo "incapturável" do autor.

Em entrevista ao site de Cultura da UFMG, Noll declara a respeito da sua experiência de writer in residence pelo King's College London na Inglaterra, onde morou convidado por essa instituição para escrever o que viria a ser o livro Lorde:
A narrativa se passa exatamente naquele espaço onde eu vivi durante três meses, Londres. Então eu bebi de cada coisa que estava ali, o ônibus que eu pegava, a casa que eu morei, o restaurante que eu almoçava... Eu não queria flash back do Brasil, nem voltar a cabeça para trás. Foi uma escrita bem instantânea, o presente se fez. ${ }^{32}$

Esse romance "parece, à primeira vista, tratar-se de uma autobiografia", ${ }^{33}$ como bem alerta o pesquisador Aquiles Brayner na orelha do livro. Todavia, para além de registrar o acontecido por meio de um confessionalismo aparente, o autor nos convida a perceber a sua figura hesitante por meio de sua "presença fantasmagórica", pois extrai de algumas experiências vividas o material para a construção de seu mundo ficcional.

Nesse sentido, muito mais do que apontar para os indícios autobiográficos em João Gilberto Noll, interessa-nos pensar como se configuram esses elementos apresentados por meio de um forte pendor de tensão entre a realidade e a representação - ou o referente e a ficção. O autor tudo fará para que essa operação se proceda, como, por exemplo, a estratégia de figurar seus personagens-narradores sob alguns de seus próprios traços fisionômicos e/ou dados biográficos como local de nascimento, nome, estado civil, idade, profissão etc. Ou mesmo, ou sobretudo, pela identificação de posições éticas
32. NOLL. O escritor de linguagem. Site de Cultura da UFMG Entrevista a Tereza Rodrigues.

33. BRAYNER. Lorde (orelha de livro).

EM TESE

BELO HORIZONTE

v. 19

N. 1

JAN.-ABR. 2013

GUIMARÃES. João-Alguém, João-Ninguém: o duplo em João Gilberto Noll

p. $59-75$ 
34. NOLL Berkeley em Bellagio, p. 49.

35. NOLL. Berkeley em Bellagio, p. 29.

36. NOLL. Berkeley em Bellagio, p. 28.

37. NOLL. Berkeley em Bellagio, p. 29. e ideológicas semelhantes entre autor e narrador facilmente constatadas em inúmeras palestras e entrevistas de J. G. Noll.

A designação de seu próprio nome, por exemplo, está em quatro de seus treze romances, a saber: A fúria do corpo, Bandoleiros, Canoas e marolas e Berkeley em Bellagio. Nesse último, quando o narrador, igualmente um reconhecido escritor brasileiro, está na cidade italiana, um estrangeiro o chama: "Joao, Joao, treinando um til com o dedo pelo ar, a repetir Joao, Joao". ${ }^{34}$ Sugere-se ainda que o sobrenome do personagem seja o mesmo do escritor, "com seu jeito aloirado, sobrenome alemão" ${ }^{35}$ Verificam-se ainda outros indefectíveis indícios biográficos: "quem era mesmo esse homem nascido em abril em Porto Alegre, no hospital Beneficência Portuguesa, às seis da manhã, criado no bairro Floresta, sem poder imaginar que um dia estaria aqui nesse castelo, ao norte da Itália, perto de Milão" ${ }^{36}$

Desse modo, por meio de interrogativas de ordem existencial, o narrador agudiza mais a sua condição humana com relação à instabilidade identitária do que simplesmente a uma condição narcísica, que se referiria somente a si mesma: "[...] hoje um escritor famoso a receber convites do mecenato internacional, mormente o norte-americano". ${ }^{77}$ Noll, assim como o personagem, também foi contratado, em 2002, por meio de uma bolsa de escritor visitante pela The Rockefeller Foundation para trabalhar nos EUA e na
Itália, países onde se passa essa narrativa. Esses biografemas, ao modo barthesiano, são encontrados de distintas maneiras ao longo de suas obras. Visto por esse ângulo, pode-se inferir que a vida do autor não é estritamente um modelo de situações análogas ao romance ou vice-versa, posto que "as cenas reais e as cenas fantasmadas não estão numa relação de filiação; todas elas não passam de duplicações paralelas, mais ou menos fortes (mais fortes na obra que na vida) de uma cena ausente, infigurada, mas não inarticulada, cujo lugar de infiguração e de articulação só pode ser a escrita", ${ }^{38}$ como bem proferiu Barthes a respeito do Marquês de Sade - "Vida de Sade".

Por mais que João Gilberto Noll evoque o seu próprio nome em seus romances, o convite é feito para negar essa alcunha, no intuito de criar uma tensão entre o real e o ficcional, na qual a identidade ou uma eventual origem se desprendam de uma patente referencialidade:

Quando acordei ouvi o sino que de hora em hora toca na Bellagio das ruelas e escadarias. Sentei e percebi que tinha perdido o meu próprio fio de história, como se acordasse, num repente, fora da cápsula que me sustentara por anos; pensei na minha idade, vi que isso para mim já não dizia nada, nem o nome que me deram na pia bastimal lembrava, se é que em algum dia me deram um nome, um corpo definido, uma imersão no tempo,

EM TESE $\quad$ BELO HORIZONTE $\quad$ v. $19 \quad$ N. $1 \quad$ JAN.ABr. $2013 \quad$ GUIMARÃES. João-Alguém, João-Ninguém: o duplo em João Gilberto Noll $\quad$ P. 59-75


39. NOLL Berkeley em Bellagio, p. 52.

se é que o tempo ainda não corre para esse ninguém que acabei sendo em meio à Fundação americana. ${ }^{39}$

Pertinente ressaltar que o nome João, não raro entre os brasileiros, designa popularmente qualquer cidadão e, por se tratar de um nome comum, revoga a si mesmo. Isto é, o nome acaba por não designar "ninguém", tornando-se um nome "neutro", cabendo junto a si qualquer predicado. $\mathrm{O}$ João é, paradoxalmente, o nome de todos e de ninguém. Negação e afirmação / marca e vazio, como sugerido por Giorgio Agamben anteriormente.

Em A fúria do corpo (1981), João conta as suas aventuras de um mendigo errante ao lado da mulher Afrodite nas ruas do Rio de Janeiro, especialmente Copacabana. Na página de abertura desse que é seu primeiro romance, escreve:

$\mathrm{O}$ meu nome não. Vivo nas ruas de um tempo onde dar o nome é fornecer suspeita. A quem? Não me queira ingênuo: nome de ninguém não. Me chame como quiser, fui consagrado a João Evangelista, não que o meu nome seja João, absolutamente, não sei de quando nasci, nada mas se quiser o meu nome busque na lembrança o que de mais instável lhe ocorrer. O meu nome de hoje poderá não me reconhecer amanhã. [... Não me pergunte pois idade, estado civil, local de nascimento, filiação, pegadas do passado, nada, passado não, nome tam-

bém: não. [... O meu nome não. Mas se quiser um nome pode me chamar de Arbusto, Carne Tatuada, Vento. ${ }^{40}$

Nessa passagem, o narrador se distingue como possuidor de uma identidade em trânsito e fora dos padrões temporais, descaracterizado de um passado que o fixaria, tornando-se ao mesmo tempo João ou qualquer outro nome - ou outra coisa -, pois tudo começa a contar a partir do momento da enunciação, inclusive a sua transformação em uma mulher ao final da narrativa: "olhando-me no espelho num tom solene: quase transfigurado numa cadência que não sou, [...] uma dama irreal se apossa do meu corpo e me reflete esguia, loura e bela qual ninfa de outras eras [...] sou alva e trêmula sou dama". ${ }^{41}$

Esse caráter multifacetado, a salvo de qualquer psicologização simples, é percebido também em Canoas e marolas (1999), romance que se passa em grande parte em uma ilha atravessada por um rio caudaloso, onde o narrador desembarca logo no início da narrativa dizendo: "Quando pequeno me chamavam de Pacífico, quase ficou meu nome". Curioso observar que esse nome também é, por um lado, um adjetivo que caracterizaria bem certa placidez, geralmente encontrada nos personagens nollianos: "Eu estava ali entre todos, [...] sem saber bem claramente o que fazia na ilha [...] / Pois eu mesmo não sabia com exatidão de mim, se adquiria um contorno pela vida ou não; meu corpo talvez resultasse
40. NOLL $A$ fúria do corpo, p. 9.

41. NOLL $A$ fúria do corpo, p. 208

42. NOLL Canoas e marolas, p. 9. 
43. NOLL Canoas e marolas, p. 32.

44. NOLL Canoas e marolas, p. 105.

45. NOLL Canoas e marolas, p. 35-6.

46. NOLL Canoas e marolas, p. 52. flutuante, informe" ${ }^{43}$ Ao final de Canos e marolas, o narrador chega ao ápice dessa passividade, anulando-se por completo, pois se torna uma "coisa" literalmente. Ele se mineraliza, transmuta-se em uma pedra no deserto. ${ }^{44} \mathrm{E}$, por outro lado, o nome Pacífico remete também à imensidão, inquietude e fluidez das águas do oceano homônimo, recordado também por outra designação no romance ao encontrar a filha que estava à procura, motivação maior de estar na ilha:

\section{"Seu nome?"}

"João. O seu?"

"Marta." / [...] "Quem é você?"

“João”, repito.

"Sim, mas João de quê?"

"João das Águas."

Essa "liquidez" do personagem-narrador agregada à alternância de seu estado petrificado -entre a ebulição e a solidez -, além da constante afirmação e negação de sua alcunh - "negando seu próprio nome, João das Águas" -,,46 produz o caráter agônico e paradoxal do projeto literário nolliano, o qual o tempo todo nos impele a tomar seus personagens como provisórios, avulsos, dispersos: deitei, fingi que adormecia, fingi tanto de tudo que cheguei a acreditar que era um navio, que fora feito só para nadar sobre as águas, João das Águas que era, carregando em minhas vísceras os dramas dos viajantes, seus temores do mar, suas dúvidas, amores passageiros ou peregrinos, tédio infinito, desejo de se atirar aos tubarões. Eu estava deitado na areia e eu era todo fingimento. ${ }^{47}$

Já em Bandoleiros, segundo romance do autor, igualmente encontramos algumas das características apontadas em Berkeley em Bellagio e em Lorde, principalmente com relação à vivência do autor no exterior e ao seu vínculo com as instituições para escrever um livro. Noll esteve por alguns meses nos EUA, financiado pelo programa de bolsas para escritores da International Writing Program/University of Yowa, em 1982. Em entrevista ao jornal O Globo, em 1985, no ano de lançamento de Bandoleiros, é revelado que o autor começou a pensar no livro durante sua viagem pelos EUA. Segundo Sheila Kaplan, essa foi a primeira vez que o autor saiu do Brasil, permanecendo "nos Estados Unidos cerca de cinco meses. [...] Esta experiência foi vital para Bandoleiros - passado entre Boston e Porto Alegre - mas não, como ele esclarece, em termos de acumulação de dados documentais, por que não é este o aspecto que lhe interessa literariamente". ${ }^{48}$ Nessa entrevista, Noll também expõe a maneira como ele traz a experiência de vida para os seus livros: "tento fazer
47. NOLL Canoas e marolas, p. 45 
um romance o menos possível com espírito de crônica. Se eu não tivesse ido aos Estados Unidos este romance jamais teria sido gestado. [...] [Portanto,] mais do que o que está sendo narrado, me interessa o empenho filosófico com que eu possa iluminar a ação dramática” ${ }^{49}$ Dessa forma, pode-se inferir que seus livros estão intimamente ligados à sua escrita subsequente e/ou concomitante às suas viagens.

As generalizações em torno do nome levantadas até aqui tomam outras particularidades em Bandoleiros, pois apesar do narrador também ser um escritor como em Berkeley em Bellagio, ele não se chama João. Ele é anônimo. Em Bandoleiros, o nome João é a designação do seu melhor amigo, de mesmo ofício: "João não tem parentes. Brincávamo até que a dele era a família mais dizimada do planeta. Então trouxe João para Porto Alegre. Para morrer junto de mim. Em dias morreu". ${ }^{50}$

É curioso observar en passant o contraste dos conteúdos expressos nas obras desses personagens-escritores (quiçá o desdobramento de uma mesma entidade, o próprio narrador/autor). Enquanto João é um escritor otimista, que acredita no bom legado da existência humana, o narrador, inominado, é um escritor incrédulo:

João responde que ando bebendo muito, que eu vá dormir que faz bem a um escritor desiludido.
João é um escritor guerreiro. Acabou de lançar um romance esperançoso. Uma história de amor na penúria. Em nossos encontros bebíamos muita cerveja. Quando eu falava de meus livros João respondia: tudo bem, mas por que esse talento todo empregado numa amargura corrosiva? Essa é a única moral possível lá nas sociedades industrializadas. E argumentava mais: olha, o eixo do novo homem vai se dar é por aqui mesmo. ${ }^{51}$

Pode-se inferir que o fato de o narrador às vezes ingerir bastante álcool altera-lhe seu estado de consciência, e assim, dado à sua embriaguez, o narrador-escritor perspectiva os acontecimentos da narrativa de forma entrecortada, justapondo-se passado, presente e futuro. Em determinados momentos, como nos elucida o pesquisador César Guimarães, chega-se ao ponto de não sabermos "com certeza se as imagens [...] pertencem ao universo de Bandoleiros, se é ao narrador que essas imagens dizem respeito, se é ele que está ali representado [...], ou se elas pertencem à narrativa que este narrador-escritor diz estar escrevendo". ${ }^{2}$ Pode-se também pensar esse romance como possuidor de um formato derivado dos recursos narrativos do cinema mais especificamente o da montagem, devido aos recursos de cenas entrecortadas, acrescidos de certa atemporalidade, a exemplo da morte de João logo no início da narrativa e do seu reaparecimento ao final.
51. NOLL. Bandoleiros, p. 77.

52. GUIMARÃES. Imagens da memória, p. 148
EM TESE

BELO HORIZONTE
N. 1

JAN.-ABR. 2013

GUIMARÃES. João-Alguém, João-Ninguém: o duplo em João Gilberto Noll

P. $59-75$ 
53. NOLL. Bandoleiros, p. 7.

56. VÁRIOS. Autores gaúchos, p. 17.
Todos esses aspectos corroboram para se pensar esse romance por um forte viés de especularização, como um desdobramento do próprio autor/narrador - um alter ego. Veja-se o que diz o narrador logo no início da narrativa:

Quando cubro João com o lençol, só até a cintura por que faz um sério verão em Porto Alegre, quando cubro João vejo que ele está indo embora.

Levo João nos braços até o carro, e ele iria morrer minutos depois, dentro do carro. No meio de um engarrafamento. ${ }^{53}$

Essa cena ilustra de maneira bastante profícua e nos sugere a pensar que para a voz do autor surgir tem de haver a sua "morte". Isto é, ser um outro diferente e igual a si mesmo - marca e vazio. Em Lorde, por exemplo, o personagem narrador, também um escritor, diz precisar abandonar de vez o que fora até então no Brasil. Ele precisa ser um outro para aderir à misteriosa tarefa de escrever um livro em Londres: "Tinha vindo para Londres para ser vários - isso que eu precisava entender de vez. Um só não me bastava agora - como aquele que eu era no Brasil..." ${ }^{54}$ É preciso, dentro dessa perspectiva, buscar ser outro para que se efetive a literatura.

João Gilberto Noll, ciente dessa dificuldade de se autorretratar por inteiro, estetiza em seus livros a impossibilidade do contato direto consigo mesmo ou com o seu duplo. Ao final de Bandoleiros, o narrador ao desembarcar de volta ao Brasil, no aeroporto do Galeão, vê o amigo João a sua espera:

João sorria, e não importava coisa alguma que ele fosse morrer. João vai. Eu vou. Todos nós vamos morrer.

Então, o que importava era aquilo mesmo - eu devolver esse largo sorriso para João, que está ali, do outro lado do vidro, me sorrindo.

E eu fui. Abandonei a mala e fui, devagarinho, gozando cada passo, e cheguei perto do vidro, e João estava ali do outro lado, com seu braço bonito dobrado para cima, a mão contra o vidro, e eu fui ali, toquei minha mão no vidro, justo na mão de João. ${ }^{55}$

Como bem salientou Márcia Hoppe Navarro a respeito desse encontro / não-encontro em Bandoleiros: "o contato dos duplos não pode se materializar, impedido pelo espesso vidro da sala de espera. Uma de cada lado do vidro, as mãos só simulam um encontro, pois o obstáculo simboliza a impossibilidade do contato na solidão inescapável em que submergem". ${ }^{56}$ Por fim, em consequência disso, torna-se em vão a procura da expressão totalitária do autor na obra, pois somente podemos tratá-la como um jogo ao modo proposto pelos autores aqui abordados. Dessa forma, em consonância com o pensamento de Giorgio Agamben,
55. NOLL Bandoleiros, p. 163

54. NOLL. Lorde, p. 28 
talvez, nessa altura, a aporia de Foucault esteja começando a ficar menos enigmática. O sujeito [...] não é algo que possa ser alcançado diretamente como uma realidade substancia presente em algum lugar; pelo contrário, ele é o que resulta do encontro e do corpo-a-corpo com os dispositivos em que foi posto - se pôs - em jogo. Isso porque a escritura [...] é um dispositivo, e a história dos homens talvez não seja nada mais que um incessante corpo-a-corpo com os dispositivos que eles mesmos produziram - antes de qualquer outro, a linguagem E assim como o autor deve continuar inexpresso na obra e, no entanto, precisamente desse modo testemunha a própria presença irredutível, também a subjetividade se mostra e resist com mais força no ponto em que os dispositivos a capturam e põem em jogo. Uma subjetividade produz-se onde o ser vivo, ao encontrar a linguagem e pondo-se nela em jogo sem reservas, exibe em um gesto a própria irredutibilidade a ela. ${ }^{57}$

\section{REFERÊNCIAS}

BIBLIOGRÁFICAS

AGAMBEN, Giorgio. Profanações. Trad.: Selvino José Assmann. São Paulo: Boitempo, 2007.

BARTHES, Roland. O rumor da língua. Trad.: Mário Laranjeira São Paulo: Martins Fontes, 2004
BARTHES, Roland. Roland Barthes por Roland Barthes. Trad.: Leyla Perrone-Moisés. São Paulo: Cultrix, s/d [1975].

BARTHES, Roland. Sade, Fourier, Loiola. Trad.: Maria de Santa Cruz. Lisboa: Edições 70, 1979 [1971].

FOUCAULT, Michel. Ditos e escritos III. Trad. Inês Autran Dourado Barbosa. Rio de Janeiro: Forense Universitária, 2001.

FOUCAULT, Michel. A ordem do discurso. Trad. Laura Fraga de Almeida Sampaio. São Paulo: Edições Loyola, 1996.

GUIMARÃES, César. Narrar por imagens: o olhar e a memória. In: _. Imagens da memória: entre o legível e o visível. Belo Horizonte: FALE; Ed. UFMG, 1997, p. 143-92.

KAPLAN, Sheila. Bandoleiros, entre Boston e Porto Alegre. $\mathbf{O}$ Globo (Rio de Janeiro), 17 de junho de 1985.

LEJEUNE, Philippe. O pacto autobiográfico: de Rousseau à Internet. Trad.: Jovita Maria Gerheim Noronha, Maria Inês Coimbra Guedes. Belo Horizonte: Ed. UFMG, 2008.

NOLL, João Gilberto. Lorde. São Paulo: Francis, 2004.

NOLL, João Gilberto. Berkeley em Bellagio. São Paulo: Francis, 2004 [2002].

NOLL, João Gilberto. Canoas e marolas. Rio de Janeiro: Objetiva, 1999

NOLL, João Gilberto. O quieto animal da esquina. São Paulo: Francis, 2003 [1991]. 
NOLL, João Gilberto. Bandoleiros. Rio de Janeiro: Rocco, 1989 [1985]

NOLL, João Gilberto. A fúria do corpo. Rio de Janeiro: Rocco, 1989 [1981].

SONTAG, Susan. Sob o signo de Saturno. Trad.: Ana Maria Capovilla, Albino Poli Jr. Porto Alegre; São Paulo: L\&PM, 1986.

VÁRIOS. João Gilberto Noll (Autores gaúchos). Porto Alegre: Inst. Estadual do Livro, v. 23, 1989.

ELETRÔNICAS, VIDEOGRAFIA E DISCOGRAFIA

CALDERON, Philippe. Foucault por ele mesmo. Arte France/ BFC Production - France, 2003.

NOLL, João Gilberto. $\mathbf{O}$ escritor por ele mesmo: leituras de João Gilberto Noll. São Paulo: Instituto Moreira Salles (IMS), n. 39, 2002.

NOLL, João Gilberto. Site oficial do escritor. Disponível em

<http://www.joaogilbertonoll.com.br>. Acesso em 17 abr. 2013.

RODRIGUES, Tereza. O escritor de linguagem - entrevista

a João Gilberto Noll. Site Cultural da UFMG. Disponível

em: http://www ufmg br/cultura/index php?option=com

content/task =viewid 60 . Acesso em 10 d 